\title{
EFFECTS OF FERMENTED MEALWORM LARVAE MEAL WITH DIFFERENT PROBIOTICS ON LITTER QUALITY IN BROILER HOUSE
}

\author{
Serkan Yazarel ${ }^{1, *}$, Şenay Sarıca ${ }^{2}$, Sedat Karaman ${ }^{3}$ \\ ${ }^{1}$ Tokat Gaziosmanpasa University, Agricultural Faculty, Department of Biosystems Engineering, Tokat, Turkey \\ ${ }^{2}$ Tokat Gaziosmanpasa University, Agricultural Faculty, Department of Animal Science, Tokat, Turkey \\ ${ }^{3}$ Tokat Gaziosmanpasa University, Agricultural Faculty, Department of Biosystems Engineering, Tokat, Turkey
}

Current Trends in

Natural Sciences

\begin{abstract}
This study was conducted to investigate the effects of the supplementation of fermented mealworm larvae meal with two different probiotic bacteria (Lactobacillus plantarum or Lactobacillus brevis) to diets of broilers reared normal or high stocking density on litter quality. Wood shavings, commonly used in broiler houses, are used as litter material. High stocking density significantly increased litter moisture content compared to that of broiler reared normal stocking density $(P<0.0001)$. Dietary supplementing of fermented mealworm larvae meal with Lactobacillus plantarum or Lactobacillus brevis significantly decreased litter moisture content compared to that of control diet $(P<0.0001)$. High stocking density significantly increased litter $\mathrm{pH}$ level compared to normal stocking density $(P<0.0001)$. On the other hand, dietary treatments had no significant effect on litter $\mathrm{pH}$. High stocking density significantly increased ammonia gas emissions in the 5 th day $(P<0.05)$ and 7 th day $(P<0.0001)$ compared to normal stocking density. Furthermore, feeding on diets supplemented with fermented mealworm larvae meal with Lactobacillus plantarum or Lactobacillus brevis numerically decreased ammonia gas emissions in the 5th and 7th days although their effects on ammonia gas emissions are not significant. It was concluded based on present findings that fermented mealworm larvae meal with probiotics can be used as a natural feed additive to prevent the problems resulted from wet litter and high indoor ammonia levels in broiler houses.
\end{abstract}

Keywords: Broiler, fermented mealworm larvae meal, litter quality, probiotic, stocking density.

\section{INTRODUCTION}

Broiler farming commonly uses ground systems worldwide and performance of production systems largely relies on proper environmental conditions including type and management of litter. In poultry farming, the greatest quantity of litter is used in broiler production. Therefore, the litter material over which broiler chickens spend most of growing period is not economically important, but quite significant in terms of functionality. Quality of the litter has significant effects on animal performance, welfare, health, behaviour and final product quality.

Broiler chickens are in continuous contact with litter throughout the entire growing period therefore litter should be able to control in terms the moisture, nitrogen and ammonia contents and microorganism population from the excreta. Its moisture, $\mathrm{pH}$, nitrogen and ammonia content and water holding capacity are the overall quality indicators of litter. Litter quality significantly influences broiler performance, immune system, productivity and thus growth rates and facility profits (Taherparvar et al., 2016). Litter material provides heat insulation and moisture absorption, 
animal excreta provide extra heat through fermentation of microorganisms, allows animal to exhibit their inherent behaviors, reduces $\mathrm{NH}_{3}$ emissions and offers a warm, soft and spongy surface of optimum comfort of the animals and provides a preventive barrier from the floor (Anonymous, 1988; Hafeez et al., 2009; Shepherd and Fairchild, 2010; Bjedov et al., 2013). On the other hand, increasing litter moisture and $\mathrm{N}$ excretion increase ammonia generation within the broiler houses. Broiler manure is one of the major sources of nitrogen pollution (Song et al., 2012), of which ammonia is a major aerial pollutant, with adverse effects on the production of broilers (Park et al., 2016). Increased release of ammonia into housing air reduces broiler feed consumption, exerts serious risks on broiler health and negatively influence broiler performance and welfare (Mayne, 2005; Shepherd and Fairchild, 2010). It is reported that dietary probiotic or prebiotic supplementation increased in nitrogen retention and reduced nitrogen excretion, thereby resulting in reduced excreta ammonia emission and improvement of nitrogen digestibility and the activity of enzymes and positively affecting the microorganism content of intestine (Park et al., 2016).

Different treatments in broiler diets are made to eliminate ammonia gas emission from wetted litter and pathogen bacteria growth in litter material. Recent research on broiler industry mostly focuses on reduction of $\mathrm{NH}_{3}$ gas emissions by the dietary supplementation of different feed additives. Probiotic or prebiotic supplementation to broiler diets play a critical role in control of manure management-induced $\mathrm{NH}_{3}$ emissions in broiler houses. In this sense, it was reported that dietary probiotic or prebiotic supplementation improved performance and feed digestibility of broiler chickens and reduced hazardous gas, especially ammonia, emissions by the positively affecting the microflora of intestine and excreta (Ahmed et al., 2014; Hossain et al., 2015; Park et al., 2016; Lan et al., 2017).

Mealworm larva meal contains \% 2.8 chitin (Veldkamp et al., 2012). The chitin content of mealworm larva meal acts as a substrate, that is, as a prebiotic, for the microbial structure of the digestive system in broiler, and affects the microbial content and the structure of microbial fermentation metabolites (Borrelli et al., 2017). With the effect of the chitinase enzyme, the chitin in the structure of mealworm larvae meal is broken down into chitooligosaccharides and shows prebiotic properties (Borrelli et al., 2017). Fermented mealworm larvae meal had both probiotic and prebiotic properties by its fermentation with two probiotic bacteria that has chitinase activity.

This study was conducted to the effects of the supplementation of fermented mealworm larva meal with two different probiotic bacteria (Lactobacillus plantarum or Lactobacillus brevis) to diets of broilers reared normal or high stocking density on litter quality.

\section{MATERIALS AND METHODS}

Experimental groups included; 1 (Control): 12 broiler $/ \mathrm{m}^{2}$ and fed diet without supplementing of fermented mealworm larvae meal, 2 (FMWLMLP): 12 broilers $/ \mathrm{m}^{2}$ and fed on diet supplemented with fermented mealworm larva meal with the Lactobacillus plantarum (0.4\%); 3 (FMWLMLB): 12 broilers $/ \mathrm{m}^{2}$ and fed on diet supplemented with fermented mealworm larva meal with the Lactobacillus brevis $(0.4 \%) ; 4$ (Control): 18 broilers $/ \mathrm{m}^{2}$ and fed diet without supplementing of fermented mealworm larvae meal; 5 (FMWLMLP): 18 broilers $/ \mathrm{m}_{2}$ and fed on diet supplemented with fermented mealworm larva meal with the Lactobacillus plantarum (0.4\%); 6 (FMWLMLB): 18 broilers $/ \mathrm{m}^{2}$ and fed on diet supplemented with fermented mealworm larva meal with the Lactobacillus brevis $(0.4 \%)$.

At the end of the experiment, $500 \mathrm{~g}$ litter samples from each sub-group were taken and homogeneously mixed, placed into vacuum bags, vacuumed and kept in a freezer until the time of 


\section{Current Trends in Natural Sciences}

Vol. 10, Issue 19, pp. 282-287, 2021

https://doi.org/10.47068/ctns.2021.v10i19.036

Current Trends in Natural Sciences (on-line)

ISSN: 2284-953X

Current Trends in Natural Sciences (CD-Rom)

ISSN: 2284-9521

ISSN-L: 2284-9521

ISSN-L: 2284-9521

analysis (Benabdeljelil and Ayachi, 1996; İpek et al., 2002). Litter samples were analyzed for moisture, $\mathrm{pH}$ and ammonia gas emissions. Litter moisture contents were determined in accordance with AOAC (2007), pH levels were determined with a digital pH meter (Hanna HI 98127, USA) in accordance with Chung (2017) and $\mathrm{NH}_{3}$ gas emissions were determined with a gas measurement device (Pro GasBadge, China) in accordance with Park et al. (2016).

\section{RESULTS AND DISCUSSIONS}

Moisture content, $\mathrm{pH}$ and ammonia gas emissions of the litter of broiler chickens raised in different stocking density and fed on diets supplemented with fermented mealworm larva meal with two different probiotic bacteria are provided in Table 1.

Table 1. The effects of experimental treatments on moisture content, pH and ammonia gas emissions of the litter of broiler chickens

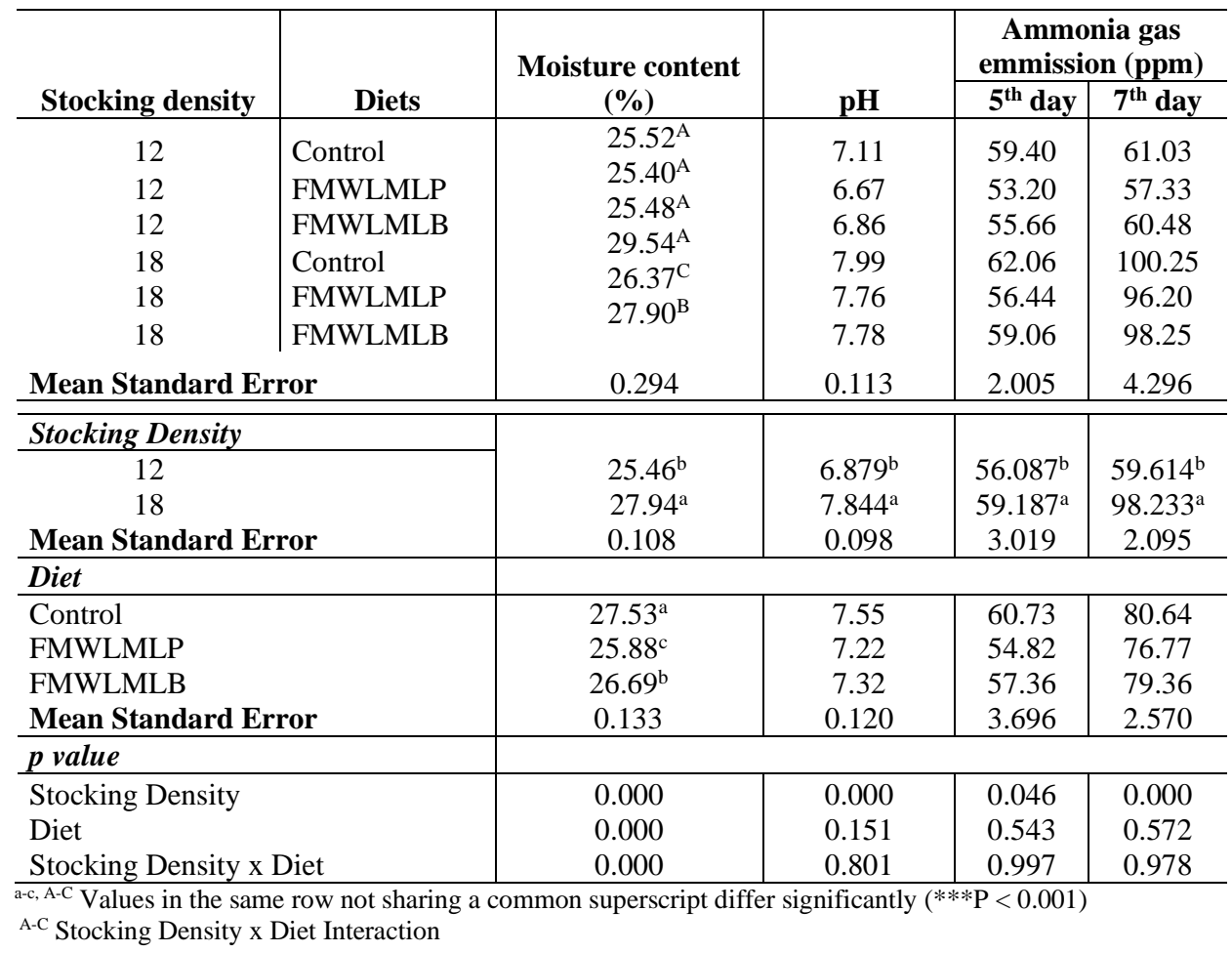

\section{Litter Moisture}

The experimental treatments significantly influenced the moisture content of litter $(\mathrm{P}<0.0001)$. The moisture content of litter was significantly affected by the stocking density $(\mathrm{P}<0.0001)$. High stocking density significantly increased the moisture content of litter compared to that of normal stocking density $(\mathrm{P}<0.0001)$. Feeding with the FMWLMLP or FMWLMLB diets significantly reduced the moisture content of litter compared to the control diet $(\mathrm{P}<0.0001)$. Morever, effect of stocking density $\mathrm{x}$ diet interaction on litter moisture content was found to be significant $(\mathrm{P}<0.0001)$. Feeding on the FMWLMLP or FMWLMLB diets did not affect the moisture content of litter when stocking density was 12 broiler/ $\mathrm{m}^{2}$. On the other hand, the moisture content of litter was significantly decreased by the FMWLMLP or FMWLMLB diets compared to the control diet when stocking density was 18 broiler/ $\mathrm{m}^{2}(\mathrm{P}<0.0001)$. Our research result is not agreement with the 
findings of Lima et al. (2018) who reported that stocking density in broiler did not influence the moisture of litter. Mahardhika et al. (2019) pointed out that supplementation of probiotics to drinking water did not affect the moisture content of litter.

\section{Litter pH}

In terms of the effects of experimental treatments on litter $\mathrm{pH}$, only the stocking density had significant effects on litter $\mathrm{pH}$ level $(\mathrm{P}<0.0001)$. High stocking density $\left(18 \mathrm{broiler} / \mathrm{m}^{2}\right)$ significantly increased as compared to the normal stocking density $\left(12\right.$ broiler $\left./ \mathrm{m}^{2}\right)(\mathrm{P}<0.0001)$. Our research result is not agreement with the findings of Lima et al. (2018) who reported that stocking density in broiler did not significantly influence the litter $\mathrm{pH}$. However, the effects of diets and stocking density $\mathrm{x}$ diet interaction on litter $\mathrm{pH}$ were not found to be significant. High competition for feed and water in high stocking density increased the feed and water quantity spilled on litter, thus increased litter $\mathrm{pH}$. Our research finding concurs with the results of Mahardhika et al. (2019) that reported that that supplementation of probiotics to drinking water did not affect the litter $\mathrm{pH}$.

\section{Ammonia Gas Emission}

Stocking density significantly influenced $\mathrm{NH}_{3}$ gas emission both in 5 th day $(\mathrm{P}<0.05)$ and 7 th day $(\mathrm{P}<0.0001) . \mathrm{NH}_{3}$ gas emissions from litter were significantly increased both 5 th day $(\mathrm{P}<0.05)$ and 7 th day $(\mathrm{P}<0.0001)$ in 18 broiler $/ \mathrm{m}^{2}$ stocking density as compared to 12 broiler/ $\mathrm{m}^{2}$ stocking density. Diets did not influence the litter ammonia gas emission both 5th day and 7th day. Contrary to our research, Mahardhika et al. (2019) demonstrated that the probiotics' supplement to drinking water significantly decreased the ammonia gas emission of litter of 35-days-old broiler chickens compared to that of broilers drinking water without probiotics. On the other hand, despite insignificant effects of experimental diets on $\mathrm{NH}_{3}$ gas emissions, dietary supplementation of fermented mealworm larvae meal with L. plantarum and L. brevis numerically reduced $\mathrm{NH}_{3}$ gas emissions in 5th and 7th days.

Ammonia is a gas from the decomposition of nitrogen waste in excreta, such as uric acid, unabsorbed proteins, amino acids and other non-protein nitrogen compounds due to the activity of microorganisms in feces. The use of probiotics or prebiotics in diet inhibits the formation of the uricase enzyme that converts uric acid in broiler chickens to ammonia gas. Dietary probiotics were able to produce bacteriocin which will be able to suppress gram-negative microbial growth so that the production of uricase enzymes are suppressed inhibiting the conversion of excreta uric acid to ammonia. The supplementation of probiotics or prebiotics can decrease ammonia formation by decreasing bacterial activity in the digestive tract (Mahardhika et al. 2019). Studies have showed that dietary supplementation of probiotics can increase the population of beneficial microorganisms and inhibit the proliferation of pathogens in the intestinal microbiota, consequently improving nutrient utilization by enhancing the activity of digestive enzymes, such as proteases, lipases and amylases (Hossain et al., 2015; Lan et al., 2017).

The reduction in ammonia gas emission occurs because the administration of probiotic or prebiotic can increase the digestibility and retention of nitrogen and reduce the nitrogen excretion so that the number of nutrients wasted in feces decreases (Park et al., 2016). Nutrients especially nitrogen are needed by microbes in feces to grow so that increasing of the number of nutrients enhances the chance of increasing the population of pathogenic microbes that are able to convert uric acid in feces into ammonia gas by the formation of the uricase enzyme (Mahardhika et al., 2019). 
However, effects of stocking density $\mathrm{x}$ diet interactions on litter $\mathrm{NH}_{3}$ gas emissions were not found to be significant.

\section{CONCLUSIONS}

It was concluded based on present findings that fermented mealworm larvae meal with probiotics can be used as a natural feed additive to prevent the problems resulted from wet litter and high indoor ammonia levels in broiler houses. It also could be concluded that the dietary supplementation of fermented mealworm larvae meal with probiotics to broiler diets may positively influence broiler health and growth and reduce excretion levels of manure and environmentpolluting nutrients.

\section{ACKNOWLEDGEMENTS}

This study presents partial results of a Phd thesis prepared by Serkan Yazarel

\section{REFERENCES}

Ahmed, S.T., Islam, M.M., Mun, H.S., Sim, H.J., Kim, Y.J. and Yang, C.J. (2014). Effects of Bacillus amyloliquefaciens as a probiotic strain on growth performance, cecal microflora, and fecal noxious gas emissions of broiler chickens. Poultry Science. 93 (8), 1963-1971.

Anonymous (1988). Quality of litter influences broiler performance, profits. Poultry International, May: 40- 44.

AOAC. (2007). Association of Official Analytical Chemists. 18th Edition W.D.C. USA.

Benabdeljelil, K. and Ayachi, A. 1996. Evaluation of alternative litter materials for poultry. Journal of Applied Poultry Research. 5(3), 203-209.

Bjedov, S., Žikić, D., Perić, L., ĐukićStojčić, M. and Milošević, N. (2013). Effect of different litter treatments on production performance of broiler chickens. Biotechnology in Animal Husbandry 29(4), 625-630.

Borrelli, L., Coretti, L., Dipineto, L., Bovera, F., Menna, F., Chiariottti, L., Nizza, A., Lembo, F. and Fioretti, A. (2017). Insect-based diet, a promising nutritional source, modulates gut microbiota composition and SCFAs production in laying hens. Scientific Reports/7: 16269/DOI: 10.1038/S41598-017-16560-6.

Chung, T. H. (2017). pH, ammonia flux and total nitrogen in duck litter with chemical blends - a field study. Revista Brasileira de Ciência Avícola. 19(4), 733-736.

Hafeez, A., Suhail, S.M., Durrani, F.R., Jan, D., Ahmad, I., Chand, N. and Rehman, A. (2009). Effect of different types of locally available litter materials on the performance of broiler chicks. Sarhad Journal of Agriculture. 25(4), $581-586$

Hossain, M.M., Begum, M. and Kim, I.H. (2015). Effect of Bacillus subtilis, Clostridium butyricum and Lactobacillus acidophilus endospores on growth performance, nutrient digestibility, meat quality, relative organ weight, microbial shedding and excreta noxious gas emission in broilers. Veterinarni Medicina. 60 (2), 77-86.

İpek, A., Karabulut, A., Canbolat, Ö. and Kalkan, H. (2002). The effects of different litter materials on the production traits of broilers. Journal of Agricultural Faculty of Bursa Uludag University. 16(2), 137-147.

Lan, R.X., Lee, S.I. and Kim, I.H. (2017). Effects of Enterococcus faecium SLB 120 on growth performance, blood parameters, relative organ weight, breast muscle meat quality, excreta microbiota shedding and noxious gas emission in broilers. Poultry Science. 96, 3246-3253.

Lima, R.C., Freitas, E.R., Gomes, H.M., Crus, C.E.B. and Fernandes, D.R. (2018). Performance of broiler chickens reared at two stocking densities and coir litter with different height. Revista Ciência Agronômica. https://www.redalyc.org/jatsRepo/1953/195358136019/html/index.html.

Mahardhika, B.P., Mutia, R. and Ridla, M. (2019). Efforts to reduce ammonia gas in broiler chicken litter with the use of probiotics. IOP Conference Series: Earth and Environmental Science. 399, 1-6.

Mayne, R.K. (2005). A review of the aetiology and possible causative factors of food pad dermatitis in growing turkeys and broilers. World's Poultry Science Journal. 61, 256- 267.

Park, J. W., Jeong, J. S., Lee, S. I. and Kim, I. H. (2016). Effect of dietary supplementation with a probiotic (Enterococcus faecium) on production performance, excreta microflora, ammonia emission and nutrient utilization in ISA brown laying hens. Poultry Science. 95, 2829-2835.

Shepherd, E.M. and Fairchild, B. D. (2010). Footpad dermatitis in poultry. Poultry Science. 89, 2043-2051. 


\section{Current Trends in Natural Sciences}

Vol. 10, Issue 19, pp. 282-287, 2021

https://doi.org/10.47068/ctns.2021.v10i19.036

Current Trends in Natural Sciences (on-line)

ISSN: 2284-953X

Current Trends in Natural Sciences (CD-Rom)

ISSN-L: 2284-9521

Song, Z.T., Dong, X.F., Tong, J.M. and Wang, Z.H. (2012). Effects of waste vinegar residue on nutrient digestibility and nitrogen balance in laying hens. Livestock Science. 150, 67-73.

Taherparvar, G., Seidavi, A., Asadpour, L., Carreira, R.P., Laudadio, V. and Tufarelli, V. (2016). Effect of litter treatment on growth performance, intestinal development, and selected cecum microbiota in broiler chickens. Revista Brasileira de Zootecnia. 45(5), 257-264.

Veldkamp, T., Van Duinkerken, G., Van Huis, A., Iakemond, C.M.M., Ottevanger, E., Bosch, G. and Van Boekel, M.A.J.S. (2012). Insects as sustainable feed ingredient in pig and poultry diets- a feasibility study. Wageningen Ur Livest. Res., Report 638. 